\title{
Research on a United Africa as Vehicle of Sustainable Development
}

\author{
Daniel Ofori \\ School of Economics, Wuhan University of Technology, \\ Wuhan, P.R. China, 430070 \\ Email: ofori006@yahoo.com
}

\begin{abstract}
The purpose of this study is to find the contribution of the unity of Africans and their descendant in the diaspora. Such unity is merely a means to the ultimate goal, which is the development and transformation of our people and the continent as a whole. The ultimate goals of such a political structure must be those of sustainable development, peace, security, growth, democracy and transformation of the continent. The source of our findings in order to achieve our objectives was obtained from secondary data and a survey was conducted by way of administering questionnaires. However, it is recommended that to achieve Africa unity, African leaders must also consider the issuing of Regional Visas (ECOWAS Visa, EAC Visa, SADC/COMESA Visa, etc) and the abolishment of individual country visas. This would also enable foreign investors the opportunity to invest in African and also encourage visitors to use a single visa thereby avoiding the long visa queues at various African embassies. Finally, there should be a common currency and Regional trade between African States.
\end{abstract}

Keywords-sustainable development; African Unity, economic growth; democracy; peace and security

\section{INTRODUCTION}

Sustainable development has become a widely recognized goal for human society ever since the deteriorating of environmental conditions in many parts of the world. Moreover, it promotes the idea that social, environmental, and economic progress that are attainable within the limits of the earth natural resources, are connected by a meanings of approaching everything in the world as being through space, time and quality of life.

Furthermore, Sustainable development is defined, as economic development that meets the needs of the present generation without compromising the ability of future generations to meet their own needs. The need of the future depends on how well Africans balance, their social, economic and environmental objectives.

Africa will continue to be one of the important continents in the world with multifaceted people from different cultural backgrounds. Interestingly, the continent is blessed with immeasurable natural resources such as crude oil, gold, iron, cobalt, uranium, copper, silver, platinum, manganese, chromium, bauxite, etc. In time past, many great leaders has sprang up in Africa notably, Kwame Nkrumah, Felix Houphouet Boigny, Nelson Mandela just to mention but a few, who has shed their blood in the course of rescuing their countries from

\author{
Oji-Okoro Izuchukwu \\ School of Economics, Wuhan University of Technology, \\ Wuhan, P.R. China, 430070 \\ Email: izulenny@yahoo.com
}

colonialism and emancipation from mental slavery. Notwithstanding, some African governments should not be proud of achieving success rather, they are seeing as weltering in the quagmire of corruption, selfishness and deceit. Consequently, regardless of African's abundant natural resources, the continent has not received any significant development.

Former Nigeria president, Olusegun Obasanjo, said that the major goal of the African Union (AU) "must be the unity of all Africans and peoples of African descendant in the diaspora. Such unity is merely a means to the ultimate goal, which is the development and transformation of our people and continent. The ultimate goals of such a political structure must be those of sustainable development, peace, security, growth, democracy and transformation of the continent." (Obasanjo's Address in Abuja, The Guardian, November 13, 2005).

The research poses a common question of what are the needs of African's in the continent? However, the continent's needs are numerous such as unemployment, political instability, lack of economic integration, inadequate quality education, inadequate industrialization, unstable exchange rate, high rate of inflation, interest rate fluctuation, inadequate infrastructure and health services etc.

The answer to this common question is unity. There is a saying that united we stand divided we fall. As stated by Chinua Achebe, that things fall apart when the centre cannot hold.

\section{REVIEW OF RELEVANT LITERATURE}

The search for African political and economic integration, which began outside Africa, finally led to the formation of the Organization of African Unity (OAU) in 1963 and was transformed into the African Union (AU) in 2002.

Despite the pursuit of divergent and competing national interests by member states, both the OAU and AU represent Africa's collective efforts in search of formal integration and development. However, the fifty-three nation-states of the AU have come to realize over time the difficulties involved in building continental unity and sustainable development in an increasingly globalized world.

Most countries in Africa are poor with an average per capita income of $\$ 600$ per year. It is also politically 
fractured and socially stratified into rich and poor, literate and illiterate groups. Which are further divided along religious lines- Traditional religions, Christianity and Islam.

The division in political and social forces has continued to chip away at Africa's fragile unity and development. However, one of the major proponents for African unity is the former the Libyan leader, Col. Muammar al-Qadhaffi, called for the immediate creation of a formal federation dubbed a "United States of Africa" as the only way to fight poverty, ignorance and a myriad of other global challenges confronting the continent.

Fifty years ago, our founding fathers outlined the followings as key priorities, We all want a united Africa. United not only in our concept of what unity connotes, but united in our common desire to move forward together. Currently, Africa is clearly fragmented into too many small uneconomic and non-viable states, of which many living in those parts of the world are finding it very difficult to survive. Therefore, this measures has called for An allAfrican planning body to take immediate steps towards the development of large-scale industry and uninterrupted power supply, removal of barriers for inter-African trade, creation of a central bank and the formation of a unified policy in all aspect of export control tariffs and quota arrangements.

Among the immediate needs in the manufacturing sectors in Africa, agricultural machineries of all kinds are needed to speed up the modernisation of agricultural produce; and also there is a need for adequate and reliable electricity power supply for industrial growth. A unified military and diplomatic policy should be realized, in order to boost the continent security and enable freedom in every country in Africa.

However the transportation and communication sectors are not left out, there is a need for unified planning of adequate construction of roads, railways, waterways, airlines and telecommunication system that will serve Africa's needs, and not the requirements of foreign interests”. Kwame Nkrumah (Neo-Colonialism, excerpts from chapter two. It was against this background that the foundation of the African Union was established in May 1963. It was a time when many African states were gradually emerging from the firm grip of barbaric colonial regimes: the regime which were so wicked that Africans at some point had no choice but to rebel against their oppression. As a reminder to our generation, Patrice Lumumba puts it best in his first ever speech as Prime Minister of then Congo: "Who will ever forget the shootings or the barbarous jail cells awaiting those who refused to submit to this (colonial) regime of injustice, oppression and intimidation?”

The organization of African Unity (OAU) was established on the 25th of May 1963, in Addis Ababa by the first Ghana President, Osagyefo Dr. Kwame Nkrumah. 32 government were signatory to the organization of African Unity (OAU) or African Union (AU) charter, later 21 states joined gradually over the years and finally South Africa became the 53rd member on 23rd May 1994. This brilliant ideas from a great legend Kwame Nkrumah was copied by the Europeans, which transpired to European Union (EU.)
The Purpose and the Principle of establishing the African Union was;

- To promote the unity and solidarity of the African States.

- To co-ordinate and intensify their cooperation and efforts to achieve a better life for the people of Africa.

- To defend their sovereignty, their territorial and independence.

- To accelerate the political and socio- economic integration of the continent.

- To promote international cooperation

- To promote sustainable development at the economic, social, and culture levels as well as the integration of African economics.

- To advance the development of the continent by promoting research in all fields, particular in science and technology.

- To work with relevant international partners in the eradication of preventable diseases and the promotion of good health on the continent.

Africa needs to keep alive the dream and vision of Mwalimu Nyerere as a shared destiny of her people. Nyerere however, emphasized that the full realization of our being lies in collective as Africans. Our freedom, strength, dignity, survival and prosperity as a people depend on our unity as Africans, for only in unity can strength be found.

As globalisation witnesses growing nationalism in other continents of the world (such as pan-Europeanism in Europe), and as Africa faces the prospect of increased marginalisation, African thinkers, intellectuals and literary icons such as Ali Mazrui, Chinua Achebe, Ngugi wa Thiong'o, Okot P'Bitek and Wole Soyinka have made passionate plead for a cultural re-awakening, which they see as a first step towards social, political and economic growth. It is argued that over-reliance on imperialist colonial languages - which by and large are emblazoned with Western world views, cultural values and ideals-is in fact neo-colonial and therefore detrimental to African unity and the spirit of pan-Africanism. A common indigenous language will not only foster unity but accommodate and manage diversity, express identity and articulate concerns for collective action and shared solutions to achieve growth and development. The AU, with a vision of transforming Africa into a closely integrated community, was to be modelled after the European Union (EU). Thereby the seventeen components of the AU were to include a Pan-African parliament, a court of justice, a central bank, and a body similar to the United Nations Security Council, with an arm to resolve conflicts on the continent.

\section{METHODOLOGY}

In other to achieve the stated objectives of the study a secondary data was sourced and utilized. A survey was conducted by way of administering questionnaires while secondary data was collected through books, newspapers, economics journals of African and the internet. Data was 
gathered from different countries in the African. 100 questionnaires were administered to test the understanding of the respondent after which the necessary corrections were made to suit the understanding of the respondents.

\section{RESUlts AND DisCUSSION}

The practical solutions to our findings are stated below, the following will be discussed extensively.

\section{A. Common Currency}

To achieve African Unity, there should be one common currency for example the "Euro" to help us facilitate trade transaction among member countries that will solve the problem of exchange rate, inflation and interest rate in business environment. Furthermore, this will allow for a central bank of Africa to regulate the financial institutions of various states in Africa.

\section{B. Free Movement Of Goods And People.}

Ideally, it would be more appropriate for African leaders to abolish individual visa to enable free movement within the continent with a unique passport in order to reduce the constraint associated with visa struggle. This would lead to economic integration and intra-African trade more realistic, reliable and profitable since all the constraint involved in free movement of goods and service are eliminated.

In the meantime, African leaders must also consider the issuing of Regional Visas (ECOWAS Visa, EAC Visa, SADC/COMESA Visa, etc) and abolish the individual country visas. This would enable the flow of foreign direct investment (FDI) which will lead to greater opportunities for investors to invest in Africa and contribute to Gross Domestic Product (GDP) of various countries, also improve the standard of living by creating employment opportunities, adequate education attainment and relevant social amenities.

Furtherance to this, the European Union currently has such a system in place where citizens of the 'third world' can acquire the Schengen visa and travel to as many EU countries as possible" "One important lesson of regional integration theory, which draws on the success of the European Union, is that the existence of elites with a shared commitment to democracy as the foundation of long-term economic cooperation and development" (Schraeder, 2004:265). Unfortunately this is not so within the African continent, African leaders have fallen short of offering such meaningful economic and political ideological consensus that is capable of transforming the continent into a modern democratic state (Ake,1996).

\section{Trade between African States.}

It is very importance for Africans to come together to fight and eradicate poverty, which has retard, our progress of sustainable development. United we stand, divided we fall. If African countries are united, it will lead to technology transfer, exchange of resources and skilled labour from one country to another, which will boost production of goods and services, and thereby reduce unemployment and increase income generation for the African populace. Practical example, Ghana, world leading producer of Cocoa, Liberia, world producer of Iron-ore and Rubber, Botswana, world producer of Diamond, Nigeria and Angola major exporter of Oil, South Africa world producer of Gold and Coal and finally Egypt world producer of Cotton just to mention a few, all these natural resources are being exported to Europe, America, Asian especially China, which will be transformed into semifinished and finished goods and then transported back to Africans with high prices. The economic implication is that Africans always create incremental job opportunities for these Europeans, Asians and Americans.

\section{CONCLUSIONS}

In conclusion, African Students in Asia, Europe and America, need to form an association to socialize and know the pertinent problems concerning our dear continent by brainstorming on good ideas that will transform Africa through innovation and creativity in order to eradicate poverty and to improve the standard of living. By innovation it means, adding value, sharing knowledge and technical skills that we have acquired from these advanced economy to Africa.

Henry Ford puts it best: "Whether you think you can or you think you can't, you are right”. Like any other revolution, indeed getting to the promise land of a One Africa, One People, is not going to be an easy task. But the bottom line is, it is possible. We simply need our leaders to believe that African Unity is possible, it is the right decision and it's long overdue. Kwame Nkrumah puts it: "Revolutions are brought about by men, who think as men of action and act as men of thought." Africa needs more men of action. We need a new generation of positive thinkers who are ready to practice what they preach. Most importantly, we need leaders who possess the 'can do' spirit.

The era when we thought Africans are not capable must cease. For there is nothing good we can achieve if we continue to see one another as strangers on our motherland. Some books written by Kwame Nkrumah, not found in African bookshops and libraries, are highly recommended that the African youth must read. It is titled: "NeoColonialism, the Last Stage of Imperialism". This is where we currently stand. Leaders and African policy makers are equally encouraged to consult this book. If this were done the dream of economically independent Africa would be a reality.

We need to encourage African investors to invest in the continent to improve employment opportunities, income flow to the people thereby reducing unemployment rate. We should also inculcate the spirit of entrepreneurship (self employment) to generate capital inflow into the continent. "Africa should seek partnerships for the mutual benefit of both investors and its people. A partnership that would transfer technology to the continent, a partnership that will create jobs, a partnership that will ensure growth and a decent life for its people”

Lastly, African leaders should consider the building of its human capital and the strengthening of existing national institutions as critical means by which Political leaders will account to their people. African leaders must also come to realize that in order to compete in an age of globalization; they also need to respond to the wind of change blowing through the continent by building a new institutional framework for a neo-liberal economic development strategy and for democratic politics in Africa. 
Africa is a very beautiful continent with immeasurable and multifarious natural resources. Despite her abundance in natural resources there is no significant reflection in her development.

\section{REFERENCES}

[1] The African Union Summit met from 21-28 January in Addis Ababa, Ethiopia, under the theme: "Pan-Africanism and African Renaissance.” The 20th Ordinary Session.

[2] Ann Seidman and Frederick Anang eds., Twenty-First Century Africa: Toward A New Vision of Self-Sustainable Development, Trenton: Africa World Press.

[3] Nkrumah Kwame Africa Must Unite, New York: International Press. Nkrumah Kwame (1970), Class Struggle in Africa, New York: International Press. (1970),

[4] Nkrumah Kwame Neo-Colonialism: The Last Stage of Imperialism,New York: International Publisher. (1965),

[5] Nkrumah, Kwame. . Education and nationalism in Africa. Educational Outlook 194318 (1): 32-40.

[6] Nkrumah, Kwame. What I mean by "positive action.” Accra, Ghana: Ministry of Information and Broadcasting. . 1950.

[7] Nyerere. J, Freedom and development (1974) Oxford: Oxford University Press.

[8] Obasanjo Olusegun "President Obasanjo's Address to African leaders in Abuja", The Guardian, November (Nov.14, 2005),14, pp.1-3,

[9] Strengthening efforts for the eradication of poverty and hunger": Ghana Country Report. The Annual Ministerial Review Meeting. Economic and Social Council (ECOSOC)- United Nations. Geneva, Switzerland. July, 2007

[10] Seidman, A, and Green, R.H, Unity or Poverty? The economics of Pan- Africanism, Harmondsworth: Penguin Books. 